Article

\title{
Impact of Sodium Hexametaphosphate on the Flotation of Ultrafine Magnesite from Dolomite-Rich Desliming Tailings
}

\author{
Duong Huu Hoang ${ }^{1,2, *(\mathbb{D})}$, Doreen Ebert ${ }^{1}$, Robert Möckel $^{1}$ (D) and Martin Rudolph ${ }^{1}$ (D) \\ 1 Helmholtz Institute Freiberg for Resource Technology, 09599 Freiberg, Germany; d.ebert@hzdr.de (D.E.); \\ r.moeckel@hzdr.de (R.M.); m.rudolph@hzdr.de (M.R.) \\ 2 Maelgwyn Mineral Services Limited, Cardiff CF24 4PA, UK \\ * Correspondence: d.hoang@hzdr.de or dhoang@maelgwyn.com
}

Citation: Hoang, D.H.; Ebert, D.; Möckel, R.; Rudolph, M. Impact of Sodium Hexametaphosphate on the Flotation of Ultrafine Magnesite from Dolomite-Rich Desliming Tailings. Minerals 2021, 11, 499. https:// doi.org/10.3390/min11050499

Academic Editors: Lev Filippov and Daniel Fornasiero

Received: 8 April 2021

Accepted: 6 May 2021

Published: 8 May 2021

Publisher's Note: MDPI stays neutral with regard to jurisdictional claims in published maps and institutional affiliations.

Copyright: (c) 2021 by the authors. Licensee MDPI, Basel, Switzerland. This article is an open access article distributed under the terms and conditions of the Creative Commons Attribution (CC BY) license (https:// creativecommons.org/licenses/by/ $4.0 /)$.
Abstract: The depletion of ore deposits, the increasing demand for raw materials, the need to process low-grade, complex and finely disseminated ores, and the reprocessing of tailings are challenges especially for froth flotation separation technologies. Even though they are capable of handling relatively fine grain sizes, the flotation separation of very fine and ultrafine particles faces many problems still. Further, the flotation of low-contrast semi-soluble salt-type minerals with very similar surface properties, many complex interactions between minerals, reagents and dissolved species often result in poor selectivity. This study investigates the flotation beneficiation of ultrafine magnesite rich in dolomite from desliming, currently reported to the tailings. The paper especially focuses on the impact of the depressant sodium hexametaphosphate (SHMP) on the following: (i) the froth properties using dynamic froth analysis (DFA), (ii) the separation between magnesite and dolomite/calcite, and (iii) its effect on the entrainment. As a depressant/dispersant, SHMP has a beneficial impact on the flotation separation between magnesite and dolomite. However, there is a trade-off between grade and recovery, and as well as the dewatering process which needs to be considered. When the SHMP increases from $200 \mathrm{~g} / \mathrm{t}$ to $700 \mathrm{~g} / \mathrm{t}$, the magnesite grade increases from $67 \%$ to $77 \%$, while recovery decreases massively, from $80 \%$ to $40 \%$. The open circuit with four cleaning stages obtained a concentrate assaying $77.5 \%$ magnesite at a recovery of $45.5 \%$. The dolomite content in the concentrate is about $20 \%$, where $80 \%$ of dolomite was removed and importantly $98 \%$ of the quartz was removed, with only $0.3 \%$ of the quartz in the final concentrate. Furthermore, the application of 1-hydroxyethylene-1,1-diphosphonic acid (HEDP) as a more environmentally friendly and low-cost alternative to SHMP is presented and discussed. Using only $350 \mathrm{~g} / \mathrm{t}$ of HEDP can achieve a similar grade (76.3\%), like $700 \mathrm{~g} / \mathrm{t}$ of SHMP $(76.9 \%)$, while obtaining a $17 \%$ higher magnesite recovery as compared to $700 \mathrm{~g} / \mathrm{t}$ of SHMP. Interestingly, the proportion of hydrophilic quartz minerals ending up in the concentrate is lower for HEDP, with only $1.9 \%$ quartz at a recovery of $21.5 \%$ compared to the $2.7 \%$ of quartz at a recovery of $24.9 \%$ when using SHMP. The paper contributes in general to understanding the complexity of the depressant responses in froth flotation.

Keywords: magnesite; dolomite; tailings; sodium hexametaphosphate SHMP; 1-hydroxyethylene-1,1diphosphonic acid HEDP; dynamic froth analyzer; froth properties; remining; pneumatic Imhoflot; reactor-separator

\section{Introduction}

Continuously decreasing ore grades and the ever-increasing demand for raw materials by a more sustainable means requires exploration and the processing of low-grade and complex ores with a fine-grained composition, the reprocessing of tailings and the beneficiation of fine-grained particles in the processing plants. However, it is broadly known that the flotation separation of fine and ultrafine particles faces many challenges, such as less effective particle-bubble collisions and reduced attachment probabilities (affecting negatively the recovery), increasing unselective entrainment and the activation of gangue, and thus the true flotation of gangue (affecting negatively the concentrate grade). 
The flotation separation of magnesium-bearing carbonates (magnesite and dolomite) from non-salt-type minerals (hematite, gold-bearing sulfides, and monazite) is typically less difficult as compared to their separation from other salt-type minerals [1]. However, the flotation of semi-soluble salt-type minerals, which contain a significant amount of $\mathrm{CO}_{3}{ }^{-2}$ along with $\mathrm{Mg}^{2+} / \mathrm{Ca}^{2+}$ ions [2-4], is generally challenging. These dissolved ions and in consequence their solution species will also interact with various minerals changing their surface properties, which interferes with the added reagents, affecting the collectormineral interactions, consuming reagents and influencing the flotation performance [1]. For instance, the $\mathrm{Ca}^{2+}$ ion can interact with $\mathrm{CO}_{3}{ }^{-2}$ to form $\mathrm{CaCO}_{3}$, precipitate on the magnesite surface and change the magnesite's surface properties, which can then be falsely depressed. Such interferences are the main reason for poor reagent selectivity, i.e., separation contrast [5]. The solution thermodynamics of the systems containing various suspended semi-soluble salt-type minerals and flotation reagents are rather complex. In addition to the dissolution of minerals and the adsorption of the dissolved mineral and reagent species at the interface, interactions between these species in the bulk can lead to complicated phenomena such as surface and bulk precipitation as well as the re-dissolution of adsorbed species [5]. Due to surface reactions, the lattice is disrupted and a new phase can be formed so that surface precipitation may occur in the interfacial or subsurface region [6]. Competition of the dissolved mineral species with similarly charged collector species for adsorption sites can result in the depression in mineral flotation. The reagents interact not only with the exposed surface of magnesite but also with dolomite and calcite, which then exhibit weak hydrophobic surface properties, leading to true flotation of these gangue minerals.

Theoretically, the flotation separation of carbonate minerals can be achieved by the direct flotation of magnesite with a depression in calcium-bearing carbonates (dolomite and calcite) and silicate gangue minerals; the reverse flotation of calcium carbonates and/or silica with a depression in magnesite, and a combination of reverse (amine) flotation of silicates and direct magnesite flotation. However, in most cases, both magnesite and calcium-bearing carbonates show similar responses to the reagents. All minerals, i.e., magnesite $\left(\mathrm{MgCO}_{3}\right)$, dolomite $\left(\mathrm{CaMg}\left(\mathrm{CO}_{3}\right)_{2}\right)$ and calcite $\left(\mathrm{CaCO}_{3}\right)$, belong to the group of semi-soluble salt-type minerals with similar cations $\left(\mathrm{Ca}^{2+} / \mathrm{Mg}^{2+}\right)$ [3].

Conventional collectors such as fatty and rosin acids have been a fairly standard family of collectors for the separation of calcium/magnesium minerals, and their mechanism of adsorption has been widely studied [7]. However, there is a tendency to absorb onto slime, i.e., fine-particle surfaces, and high temperature is often a requirement with relatively high reagent consumption. The application of fatty acids as the collectors along with the depression in gangue minerals is the conventional way to selectively separate calcium/magnesium minerals. However, this has a low selectivity, limited success and increasing processing costs, hence it is not always satisfactory on an industrial level [8]. Therefore, different types of collectors are considered in the flotation of calcium-bearing minerals $[8,9]$, including oleates, hydroxamates, sulfosuccinates and sarcosinate. The mixtures of collectors have been showing more favorable improvements on selectivity than using only one collector [8,10-13]. However, in the absence of depressants or modifiers, the collector's responses to both magnesite and calcium carbonate gangues (dolomite and calcite) are similar, their recoveries are in roughly equal proportion and the overall flotation is not selectively efficient $[1,14,15]$. The depressants play a critical role in improving the selectivity, especially for the flotation separation of semi-soluble salt-type minerals.

Furthermore, it is widely known that the main uses of depressant regulators in flotation are their great capability for dispersion, modification of froth properties, control of $\mathrm{pH}$, precipitation and/or complexation of metallic ions, and modification of collector action $[1,16]$. In semi-soluble salt flotation systems, the main depressants are including inorganic and organic $[17,18]$, e.g., sodium carbonate, sodium silicate, sodium pyrophosphate [19], sodium hexametaphosphate (SHMP), starch, carboxymethyl cellulose (CMC), quebracho and tannin derivatives [20]. However, due to the similarity in surface properties 
of magnesite and calcium-bearing carbonates, the depressants not only depress gangue minerals but can also depress the valuable mineral. The fine particles have interactive effects on each other that could depress another mineral [21], the fine particles of magnesium carbonates can coat the surface of their associated mineral and depress them [22-24]. SHMP can also interact with free calcium/magnesium ions in the pulp and prevent the formation of unwanted salt minerals. The interaction between the depressants, free ions, other reagents and mineral surfaces in the semi-soluble salt-type minerals is very complex.

Yin et al. [25] indicated that a chelation inhibitor 1, 2-bis (o-aminophenoxy) ethane$\mathrm{N}, \mathrm{N}, \mathrm{N}^{\prime}, \mathrm{N}^{\prime}$-tetra acetic acid (BAPTA) can improve the separation efficiency of magnesite and dolomite. However, it has high production costs and the studies were conducted on single minerals, limiting the utilization to industrial practice [14]. Sodium hexametaphosphate (SHMP, $\left.\left(\mathrm{NaPO}_{3}\right)_{6}\right)$ is often used in water treatment as a water softener, which prevents the formation of unwanted salts such as limescale and the interference with some cations $\left(\mathrm{Ca}^{2+}\right.$, $\mathrm{Mg}^{2+}, \mathrm{Fe}^{2+/ 3+}$, etc.). In mineral flotation, it is used as a depressant, and it is well known that it has an excellent capability of dispersion, complexation of metal ions and modifications of reagent action [1]. However, it had a wastewater problem and as a dispersant, thus negatively affecting the liquid-solid separation, such as filtration and thickening processes.

Despite only a few studies addressing the impact of sodium hexametaphosphate on sulfide ore flotation in seawater [26-29], very little attention has been paid to the semisoluble salt-type minerals, in particular for the magnesite ore containing carbonate gangue minerals (dolomite, calcite).

Luo et al. [15] stated that using sodium carbonate as a regulator/co-depressant [30] together with SHMP gave better recovery compared to using SHMP alone. Also, the reagents addition order is essential when the SHMP is added prior to $\mathrm{Na}_{2} \mathrm{CO}_{3}$, eliminating the adverse effect of $\mathrm{Ca}^{2+}$. SHMP interacts with $\mathrm{Ca}^{2+}$ or $\mathrm{Mg}^{2+}$ ions, preventing the formation of $\mathrm{CaCO}_{3}$ or $\mathrm{MgCO}_{3}$ on the mineral surfaces, which reduces the hydrophobicity of the magnesite surface. However, we have conducted some tests using different addition orders but obtained negative results, there was an increased consumption of the collector to achieve the same recovery.

Further, 1-hydroxyethylene-1,1-diphosphonic acid (HEDP) has been used as an environmental water treatment reagent due to its low cost and excellent anti-scaling performance in an aqueous solution to prevent the precipitation of calcium salts, i.e., in low-pressure boilers, oil field operations and cool-water systems [31]. Recently, the application of HEDP serving as a flotation reagent showed a promising result. Huang et al. [32] found that HEDP has been used as a selective flotation reagent of chalcopyrite against pyrite. HEDP has also been proven to be a good fluorite inhibitor in separating fluorite from calcite via reverse flotation [33]. Furthermore, a recent study by Yang et al. [14] using HEDP as a depressant in single-phase minerals displayed a very selective depression in dolomite due to the HEDP strongly adsorbing onto the dolomite with a higher calcium site density [14], whereas it had only slightly shown to depress magnesite.

This present study investigates the effect of SHMP on the flotation separation of ultrafine magnesite rich in dolomite from desliming tailings in the lab batch scale. Its impact on the pulp and froth properties, using additional sedimentation tests and a dynamic froth analyzer (DFA), support the investigation to understand how SHMP application links the flotation performance, entrainment and downstream processes. Furthermore, the paper also presents the application of HEDP as a selective depressant, which could be considered for SHMP's replacement.

\section{Materials and Methods}

\subsection{Materials}

Magnesitas Navarras (Magna) was founded in 1945. Magna is one of the world's leading companies as a vertically integrated producer of magnesium oxide (MgO)-based solutions and materials for the steelmaking, agriculture, livestock and environmental sectors. The beneficiation of the mineral has different process and one of them is the 
flotation of low-grade magnesite. At this stage, the ore is ground to below $0.2 \mathrm{~mm}$ for the sake of liberation. The mill discharge is passed through a hydrocyclone to separate the slimes $(-25 \mu \mathrm{m})$ to the tailings ponds, with a mass pull of approx. $20 \%(w / w)$. Flotation is only conducted on the underflow with the particle size about $25 \mu \mathrm{m}-200 \mu \mathrm{m}$ and involves two-stage flotation, i.e., amine flotation to remove silicates and direct flotation of magnesite.

The material used in this study is the cyclone overflow $\left(d_{80}=17 \mu \mathrm{m}\right)$, so-called slime tailings. It is currently discharging to the tailings ponds due to no suitable separation method to treat this fine material. The fine reject contains about $52.3-60 \%(w / w)$ magnesite, $33-36.9 \%$ dolomite, $3-3.5 \%$ calcite, $3.4-4.4 \%$ quartz and $3.4 \%$ other minerals (see Section 3.2).

\subsection{Reagents}

Sodium carbonate $\left(\mathrm{Na}_{2} \mathrm{CO}_{3}, 99.9 \%\right)$ as a $\mathrm{pH}$ regulator was used to achieve an alkaline environment, it also acts as a co-depressant/multi-faceted reagent [30]. Sodium silicate $\left(\mathrm{Na}_{2} \mathrm{SiO}_{3}\right)$ as a dispersant agent, also depressant, with a purity of $99 \%$, was supplied by Zschimmer \& Schwarz GmbH \& Co. KG, Burgstädt, Germany. Sodium hexametaphosphate (SHMP $/ \mathrm{Na}_{6} \mathrm{O}_{18} \mathrm{P}_{6}$ ) was supplied by Alfa Aesar. The 1-Hydroxyethane-1,1-diphosphonic acid (HEDP) was used as depressant, with a purity of $90 \%$, from Carl Roth GmbH. Methyl isobutyl carbinol (MIBC) was utilized as a frother provided by Sigma-Aldrich, Steinheim, Germany. The Resanol A100 was used as a magnesite collector provided by Ekof GmbH, Bochum, Germany. Short reagent conditioning time and staged addition were applied to prevent the slime generation and reagent consumption [1], i.e., SHMP, HEDP and Resanol A100 were added in at different steps, the first addition to receive concentrates 1 and 2 . Then the air supply was stopped. The additional reagents were added and conditioned before air is turned back on and concentrates 3 to 5 are collected. The detailed reagents regimes used are given in Table 1.

Table 1. Reagents regimes used in flotation tests.

\begin{tabular}{|c|c|c|c|c|}
\hline Type & Name & Purpose & Dosage & $\begin{array}{c}\text { Conditioning } \\
\text { Time (min) }\end{array}$ \\
\hline \multirow[t]{2}{*}{$\mathrm{pH}$ regulator } & Sodium carbonate $\left(\mathrm{Na}_{2} \mathrm{CO}_{3}\right)$ & pH adjustment (co-depressant) & (to reach $\mathrm{pH} 10$ ) & 5 \\
\hline & Sodium silicate $\left(\mathrm{Na}_{2} \mathrm{SiO}_{3}\right)$ & depresses silicates mainly & $300 \mathrm{~g} / \mathrm{t}$ & 2 \\
\hline \multirow[t]{2}{*}{ Depressant } & $\begin{array}{l}\text { Sodium hexametaphosphate } \\
\qquad \mathrm{Na}_{6} \mathrm{O}_{18} \mathrm{P}_{6}\end{array}$ & $\begin{array}{l}\text { depresses calcium-bearing } \\
\text { carbonate gangue mainly }\end{array}$ & $\begin{array}{c}(100-600) \mathrm{g} / \mathrm{t} \text { (additional } 2 \times 50 \mathrm{~g} / \mathrm{t} \\
\text { added before } \mathrm{C} 3 \text { and } \mathrm{C} 4\end{array}$ & 2 \\
\hline & $\begin{array}{l}\text { 1-Hydroxyethane-1,1-diphosphonic } \\
\text { acid (HEDP) } \mathrm{C}_{2} \mathrm{H}_{8} \mathrm{O}_{7} \mathrm{P}_{2}\end{array}$ & $\begin{array}{l}\text { depresses calcium-bearing } \\
\text { carbonate gangue mainly }\end{array}$ & $\begin{array}{c}200 \mathrm{~g} / \mathrm{t}+3 \times 50 \mathrm{~g} / \mathrm{t} \text { added before } \\
\text { C3, C4 and C5 }\end{array}$ & 2 \\
\hline Collector & Resanol A100 & magnesite collector & $\begin{array}{c}300 \mathrm{~g} / \mathrm{t}, \text { then } 3 \times 300 \mathrm{~g} / \mathrm{t} \text { added } \\
\text { before C } 3, \mathrm{C} 4 \text { and } \mathrm{C} 5\end{array}$ & 3 \\
\hline Frother & Methyl isobutyl carbinol (MIBC) & frother & $30 \mathrm{~g} / \mathrm{t}$ & 2 \\
\hline
\end{tabular}

\subsection{Froth Flotation Experiments}

The flotation tests were carried out using a $2 \mathrm{dm}^{3}$ Outotec GTK laboratory mechanical cell. The reagents were conditioned at a high solid concentration at $60 \%(w / w)$, i.e., $150 \mathrm{~g}$ of fine magnesite ore and $100 \mathrm{~mL}$ of tap water. After conditioning with the reagents, the slurry is transferred into the $2 \mathrm{dm}^{3}$ cell. Another $1700 \mathrm{~mL}$ of tap water is added to achieve a solid content of $7.7 \%(w / w)$. The pulp density is chosen to be relatively low due to the ultrafine size of the feed [34].

The impeller speed and airflow rate were adjusted to $1200 \mathrm{~min}^{-1}$ and $2 \mathrm{~L} / \mathrm{min}$ (normal condition). The pulp's $\mathrm{pH}$ after adding fine magnesite lies at about 8.8, using $\mathrm{Na}_{2} \mathrm{CO}_{3}$ it is adjusted to $\mathrm{pH}$ 10. Also, the pulp level is kept constant by adding tap water into the flotation cell when required.

For the cleaning stages, in order to have a similar pulp density, the rougher flotation was conducted twice. The concentrates from the two roughers were then transferred to the first cleaner stage. The concentrate of the first cleaner then feeds the second cleaning and 
so on. Four cleaning stages have been conducted. There were no additional reagents prior to the cleaning stages.

After carrying out the flotation tests, all the concentrates, middlings and final tailings were filtered, dried and weighed. For the mineralogical characterization, the concentrates and tailings were analyzed with XRD and Rietveld analysis at the Helmholtz Institute Freiberg for Resource Technology (HZDR/HIF), Freiberg, Germany.

\subsection{Sedimentation Test}

The suspensions used in sedimentation tests received the same conditioning as used in the flotation test, including high solid concentration conditioning and then dilution with tap water. Only $75 \mathrm{~g}$ of fine magnesite samples were conditioned with $50 \mathrm{~g}$ tap water in a $400 \mathrm{~mL}$ beaker with reagents added at speed $600 \mathrm{rpm}$. The reagent regime was similar to the batch flotation (cf. Section 2.3), the sodium hexametaphosphate dosage was varied, i.e., $0 \mathrm{~g} / \mathrm{t}, 100 \mathrm{~g} / \mathrm{t}, 200 \mathrm{~g} / \mathrm{t}, 300 \mathrm{~g} / \mathrm{t}, 400 \mathrm{~g} / \mathrm{t}$ and $700 \mathrm{~g} / \mathrm{t}$. After conditioning, the pulp was transferred into a $500 \mathrm{~mL}$ graduated cylinder with a diameter of $54 \mathrm{~mm}$. The cylinders were stoppered and shaken manually for $1 \mathrm{~min}$, the cylinders were then left to stand and the height of sediment was read by time. The sedimentation ratio was calculated as the ratio of the height of the clear water $H_{t}$ at the time $t$ to the initial (total) height $H_{0}$ of suspension. Also, the settling speed $\left(v_{\text {settling, } t}\right)$ was defined as the different height $\Delta H(t)$ between initial height $H_{0}$ and the height of the clear water $H_{t}$ at the time $t$ divided by the settling time $t$.

\subsection{Dynamic Froth Analysis}

Up to now, to the best of our knowledge there is no investigation on how depressants such as SHMP affect the froth properties by means of froth stability. While conducting the flotation tests, it is observed that the froth appearance was changed with the change in depressant dosages. To evaluate the effect of SHMP on the froth ability and froth stability (i.e., froth height with time and bubble size distributions) and better understand how this links to the flotation results, the dynamic froth analysis (DFA) is used. In the DFA technique, the froth rises within a column and the height is measured as a function of time. A more detailed description of the measurement procedures can be found by Hoang et al. [35].

Several indicators have been introduced for the assessment of the froth stability, including froth half-life time, froth maximum height at equilibrium, bubble growth across the froth phase, air recovery and solid loading on bubbles on the top of the froth surface, froth velocity, and froth rising velocity [36]. The maximum height can be well correlated with the frothing ability and froth stability [37,38]. Bikerman [39] introduced the dynamic stability factor $\left(\sum\right)$ as the ratio of the maximum volume of generated foam or froth to the gas flowrate given by Equation (1). This factor has been used in froth flotation studies, e.g., by Mackay et al. [40], and McFadzean et al. [41,42].

$$
\Sigma=\frac{V_{f}}{Q}=\frac{H_{\max } A}{Q},
$$

where $V_{f}$ is the froth volume, $Q$ is the gas flowrate, $H_{\max }$ is the maximum equilibrium height and $A$ is the cross-sectional area of the column.

The half-life time of the bubbles can be used to evaluate froth stability as well. In this study, it is determined as the times between the reached maximum froth height and stable froth.

The pulp suspensions used for the dynamic froth analysis are prepared such as the ones used in the batch flotation and sedimentation tests. The fresh suspensions have been prepared for each test to prevent aging effects of the pulp properties. Each condition had been measured in triplicates. A $60 \mathrm{~mL}$ sample of this pulp is transferred to a transparent glass column of $40 \mathrm{~mm}$ inner diameter of the DFA-100 (Krüss, Germany). The froth is generated by bubbling air through a ceramic frit (pore diameter $16 \mu \mathrm{m}-45 \mu \mathrm{m}$ ) at $0.4 \mathrm{~L} / \mathrm{min}$ air flow rate for a constant duration of $100 \mathrm{~s}$. The froth properties, including its height and structure, are recorded to evaluate dynamic parameters of the frothing ability, froth stability 
and time-dependent bubble size distributions. The bubble size distribution is observed at a fixed camera position $(60 \mathrm{~mm})$, froth height and employing an adapted image processing algorithm described in Section 3.3.2 below.

\subsection{Mineral Liberation Analysis and Quantitative Phase Detection}

Representative feed samples were prepared as A-side grain mounts as described in [43], and they were carbon coated. MLA is an FEI Quanta 650F scanning electron microscope equipped with two Bruker Quantax X-Flash 5030 EDX detectors and FEI's MLA Suite 3.1.4 for automated data acquisition [44]. MLA measurements were conducted at the Helmholtz Institute Freiberg using the GMAP method and at an accelerating voltage of $25 \mathrm{kV}$ and a beam current of $10 \mathrm{nA}$. The details of the MLA measurements can be found elsewhere $[45,46]$. The feed, concentrates and tailings were analyzed using $X$-ray diffraction (XRD) and quantitative compositional information is retrieved with the Rietveld method. A PANalytical Empyrean X-ray diffractometer with a Co tube (with primary Fe filter) was used and operated at $35 \mathrm{kV}$ and $35 \mathrm{~mA}$, the device was equipped with a PIXcel 3D medipix $1 \times 1$ area detector. The measurement range was $5-80^{\circ} 2$ theta with a step size of $0.013^{\circ}$ 2 theta, and the measurement time was $2.5 \mathrm{~h}$. The PDF-4+ 2020 database (ICDD) and Highscore software package of PDF-4+ PANalytical as well as the BGMN/Profex software package [47] were used for the data evaluation.

\section{Results and Discussions}

\subsection{Particle and Grain Sizes}

Figure 1 displays the particle and mineral grain size distributions as derived from the MLA data, with the representative particle/grain size being the equivalent equal circle diameter (ECD). The slime magnesite tailings sample comprises slightly coarser dolomite and finer-grained quartz and other minerals. It can be seen in Figure 1 that the mean particle size and $\mathrm{d}_{80}$ are approximately $14 \mu \mathrm{m}$ and $17 \mu \mathrm{m}$, respectively. The ultrafine particles cause the challenge in conventional froth flotation. Also, ultrafine hydrophilic quartz is another issue affecting the entrainment in the case of the direct flotation of magnesite.

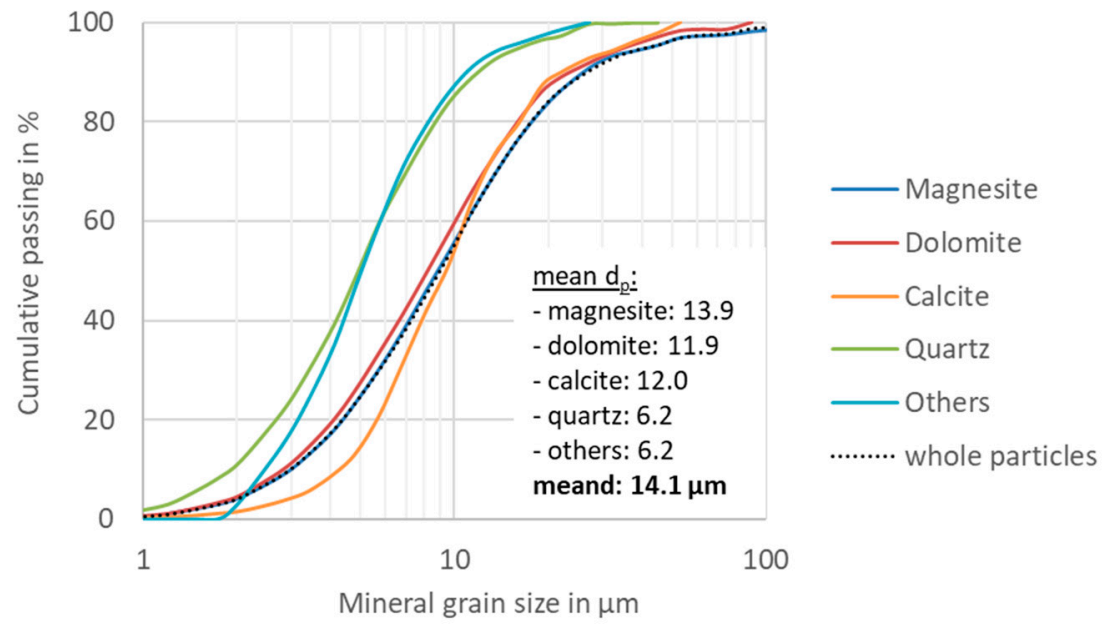

Figure 1. Cumulative particle and mineral grain size distributions derived from MLA with the size being the equivalent circle diameters (ECD) of the particle/grain sections.

\subsection{Mineral Composition and Liberation}

Figure 2 and Table 2 illustrate the mineral composition of the fine magnesite ore, which was analyzed by automated mineralogy (MLA) and XRD. The MLA measurement shows that the magnesite grade is lower than the grade determined by XRD, while the dolomite content is higher as analyzed with MLA (Table 2). It is in general an analytical challenge to distinguish between ultrafine magnesite and other magnesium-carbonate phases due 
to mineralogical property similarities between the two minerals. Also, the discrepancy between the two methods might be caused by the minimum detectable ultrafine grain size for MLA, i.e., below $5 \mu \mathrm{m}$. In addition, the XRD measurements indicate that there was no significant differential effect of regrinding due to the fine particles (Table 2). Therefore, all the concentrate and tailings samples were handled with XRD without further grinding. Furthermore, the back-calculated mineral composition from the concentrates and tailings are similar to the feed. It demonstrates that the sample preparation and chemical analysis are representative and accurate.

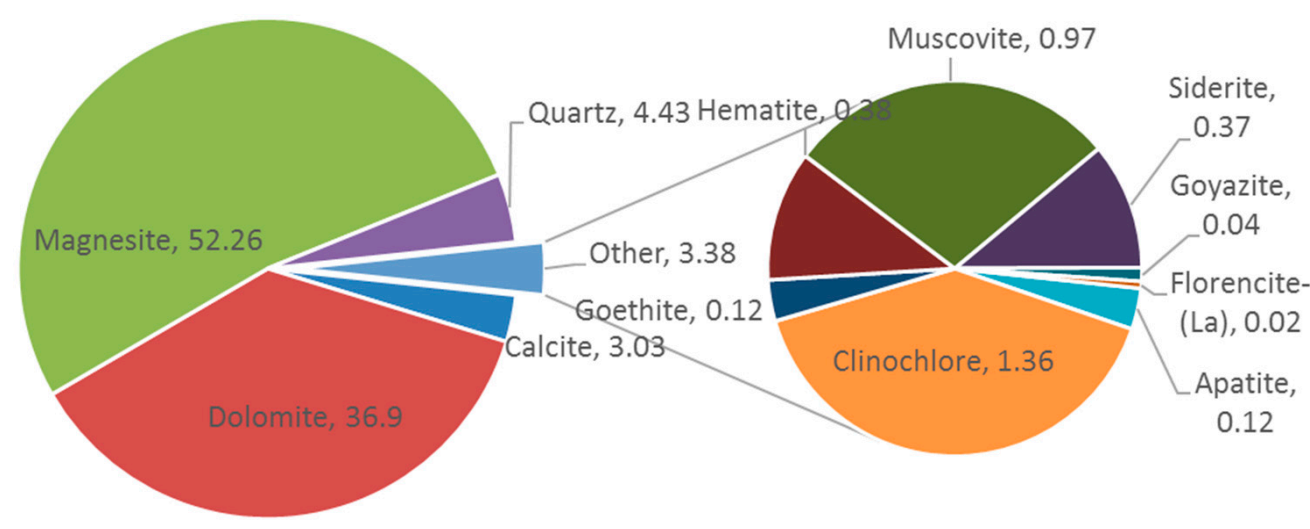

Figure 2. Mineral composition (values as $\%(w / w)$ ) as analyzed by MLA.

Table 2. Comparison between MLA and XRD measurements.

\begin{tabular}{ccccc}
\hline \multirow{2}{*}{ Mineral } & MLA, $\%(w / w)$ & \multicolumn{3}{c}{ XRD, $\%(w / w)$} \\
\cline { 3 - 5 } & & with Fine Milling & without Milling & Back-Calculated (Products from Flotation Tests) \\
\hline magnesite & 52.2 & 58.9 & 60.3 & 59.8 \\
dolomite & 36.9 & 33.9 & 33.2 & 33.0 \\
calcite & 3.0 & 3.1 & 3.2 & 3.5 \\
quartz & 4.4 & 4.1 & 3.4 & - \\
others & 3.4 & - & - & 100.0 \\
total & 100.0 & 100.0 & 100.0 & \\
\hline
\end{tabular}

The ore contains about $52.3-60 \%(w / w)$ magnesite, 33-36.9\% dolomite, 3-3.5\% calcite, $3.4-4.4 \%$ quartz and $3.4 \%$ other minerals (mainly clinochlore and muscovite). The main problematic gangue minerals are dolomite and calcite. All the valuable magnesite $\left(\mathrm{MgCO}_{3}\right)$, unwanted dolomite $\left(\mathrm{MgCa}\left(\mathrm{CO}_{3}\right)\right)$ and calcite $\left(\mathrm{CaCO}_{3}\right)$ gangue minerals belong to the group of semi-soluble salt-type minerals, exhibiting similar surface properties to magnesite (solubility, surface species, zeta potential) as well as similar responses to reagents.

The mineral association results from MLA are given in Figure 3. The main gangue interlocked with magnesite consists mostly of dolomite and a bit of calcite. On the other hand, it shows that dolomite is associated mainly with magnesite.

Figure 3 displays that the main gangue interlocked with magnesite consists of dolomite $(66.5 \%)$. In contrast, magnesite is the main mineral associated with dolomite $(52.9 \%)$.

The theoretical grade-recovery is given in Figure 4 . It can be seen that both the valuable magnesite and gangue minerals are well liberated. However, there is a lower liberation for the calcite. 


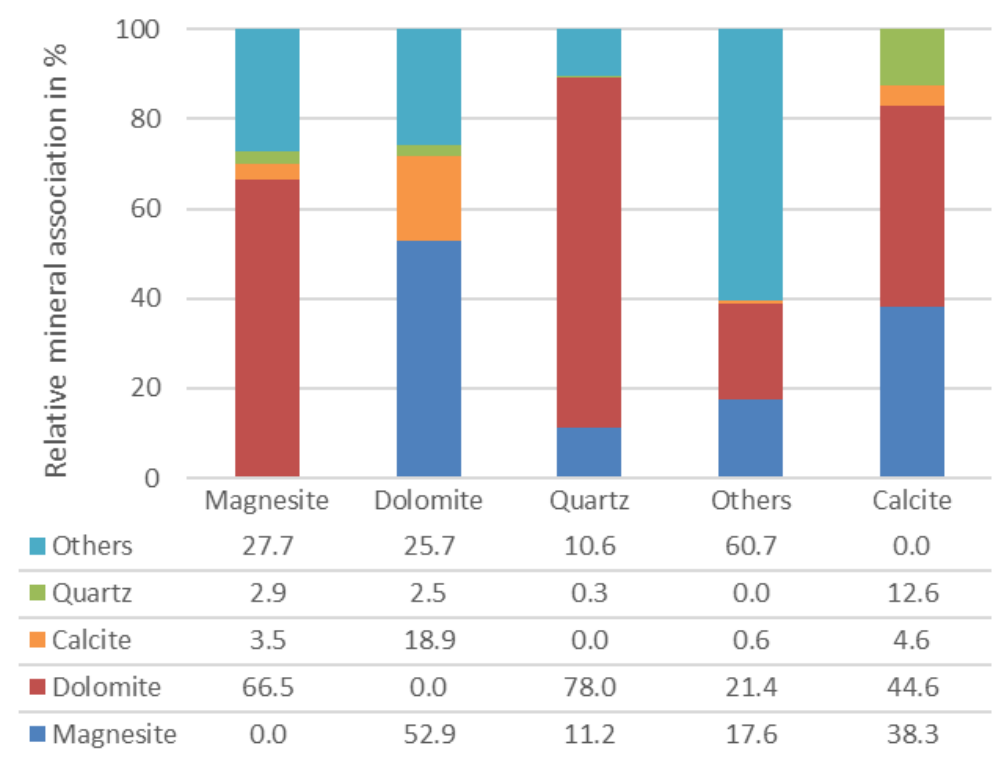

Figure 3. Mineral association (as analyzed with MLA).

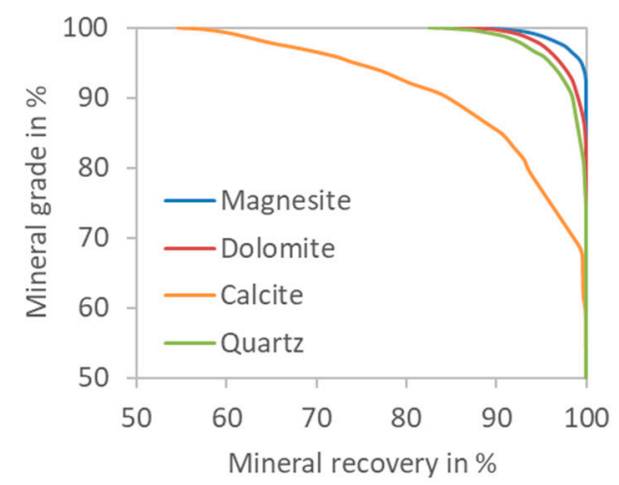

Figure 4. Mineralogical limiting curves (as analyzed with MLA).

\subsection{Froth Properties}

3.3.1. Frothing Ability and Froth Stability

As mentioned above, SHMP is often used in water treatment as water softener, which prevents scaling by the precipitation of calcium and magnesium salts. In the three-phase system, with the presence of the semi-soluble salt-type minerals, many complex interactions between ions, reagents and mineral surfaces occur within the bulk solution. Hence, SHMP is expected to have a significant effect on the pulp and froth properties in general. Figure 5 shows that as the SHMP concentration increases, the froth height decreases, decreasing the frothing ability, and resulting in a lower recovery (see Section 3.5.2). We assume that the SHMP interacts with free $\mathrm{Mg}^{2+}$ andCa ${ }^{2+}$ ions in the bulk. Hoang et al. [48] argued that the attached fine particles on the bubble surfaces can prevent the bubble coalescence, reducing the bubble burst rate, thus increasing both the frothing ability as well as the froth stability. The higher solid content within the froth phase for the lower SHMP concentration (see Figure 13) could in addition be an influence on the frothing ability. After the froth reached its maximum height, it reduced quickly while the gas flow rate was constant still and before bubbling was stopped at $100 \mathrm{~s}$, which corresponds to the froth stability, i.e., bubble burst rate (Figure 5). 


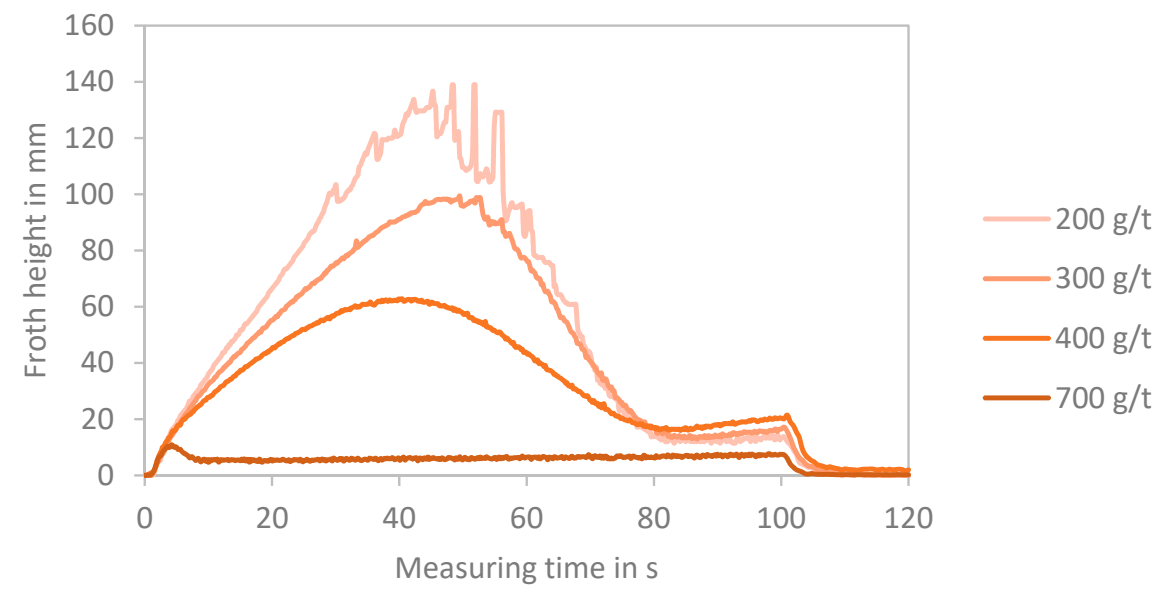

Figure 5. Froth height as a function of measuring time during growth of froth of pulp samples at different SHMP concentrations as determined with the DFA method.

The dynamic stability factor $\sum$ calculated using Equation (1), where $h_{\max }$ is determined from Figure 5, $A=1256.6 \mathrm{~mm}^{2}$ and $Q=0.4 \mathrm{~L} / \mathrm{min}$. Figure 6 displays both the half-life time of the bubble $\left(t_{1 / 2}\right)$ and the dynamic stability factor $\sum$ decreasing with an increased SHMP dosage. The dynamic stability factor $\sum$ reduced from 0.47 to 0.03 with an increasing SHMP dosage from $200 \mathrm{~g} / \mathrm{t}$ to $700 \mathrm{~g} / \mathrm{t}$, respectively. The decreasing in the dynamic stability factor and half-life time of the bubbles, with an increasing in the SHMP concentration, causes the reduction in the recovery (see Figure 11) and the entrainment of the fine gangue particles (Figure 14).

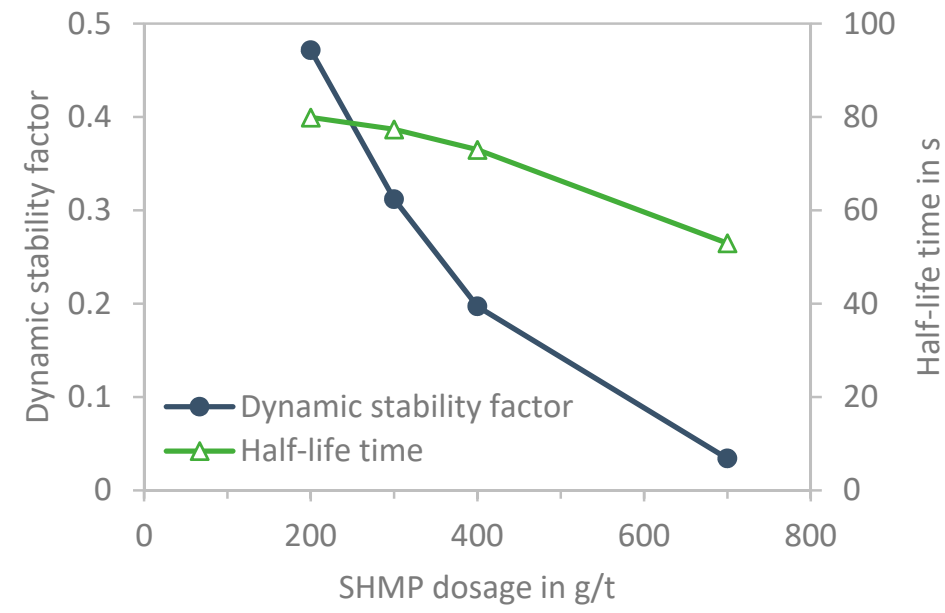

Figure 6. Half-life time of bubble $t_{1 / 2}$ and dynamic stability factor $\sum$ as a function of SHMP concentration as determined with the DFA method.

\subsubsection{Image Processing and Bubble Size Evaluation}

The image processing is treated similarly to the method proposed by Boos et al. [49], which was described by Hoang et al. [35]. Firstly, Gaussian filtering with a radius of 20 pixels is employed in order to smoothen distortions from the particles positioned inside the lamellas (Figure 7b). Subsequently, binarization (Figure 7c) and a skeleton transformation (Figure 7d) virtually removes the thick, wall-touching Plateau borders and reveals the contact lines of the lamellas at the wall separating the bubbles. Each area bound by a set of contact lines represents the contact area of one bubble with the wall. Segmentation (Figure 7d) yields the size of all the contact areas in the field of view. 
The objects close to the rim of the image or with an area smaller than $10 \mathrm{px}^{2}$ are ignored. The blue circles in Figure $7 \mathrm{~d}$ mark all the accepted bubble contact areas.
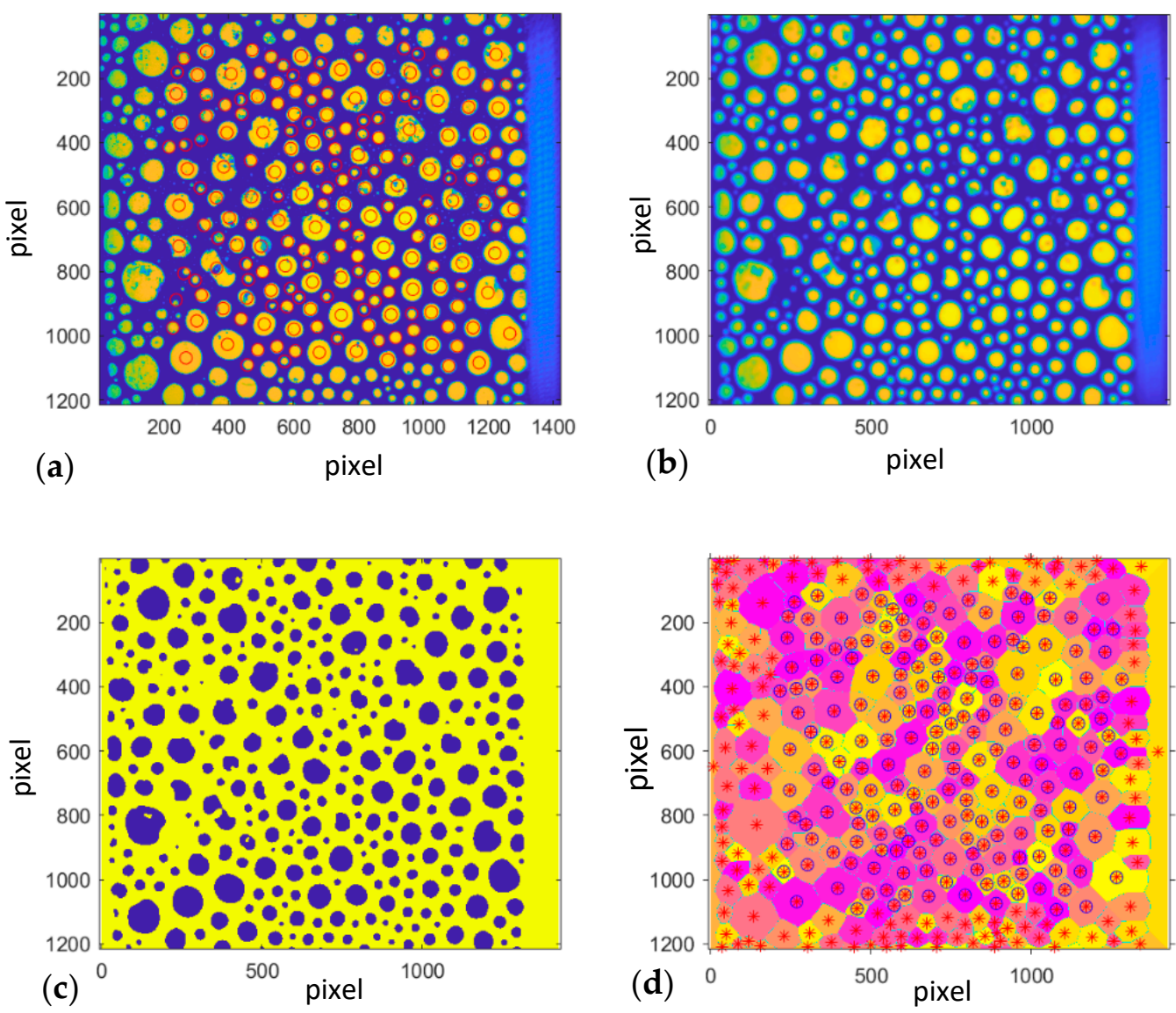

Figure 7. Bubble size evaluation with original frame obtained from DFA 100. (a) Filtered image; (b) binarized image; (c) the cell skeleton image; and (d) analyzed bubbles are marked with a circle [35].

The bubble size is represented by the equivalent spherical radius $r$ of the bubble volume and the contact area size is denoted by its equivalent circular radius $r_{s}$. Using the Surface Evolver, Wang and Neethling [50] found the statistics for the relation of $r$ and $r_{s}$ to be the following:

$$
f\left(\frac{r_{s}}{r}\right)=\frac{3.51\left(r_{s} / r\right)^{4.61}}{1+\exp \left(47.96\left(r_{s} / r-1.08\right)\right)} .
$$

The bubble size distribution of all the bubbles from all the images presented in Figure 8 shows that the bubble sizes are increased with the increasing SHMP concentration. These findings are in line with the changes in the froth height and reagents concentration, and the reduction in the solid content in the froth phase, thus there are higher chances for bubble coalescence while increasing the bubble burst rate as well as increasing SHMP dosage. This is certainly assuming that the semi-equilibrium bubble size within the pulp is not affected by the SHMP concentration, which is an assumption to be checked in future studies. 


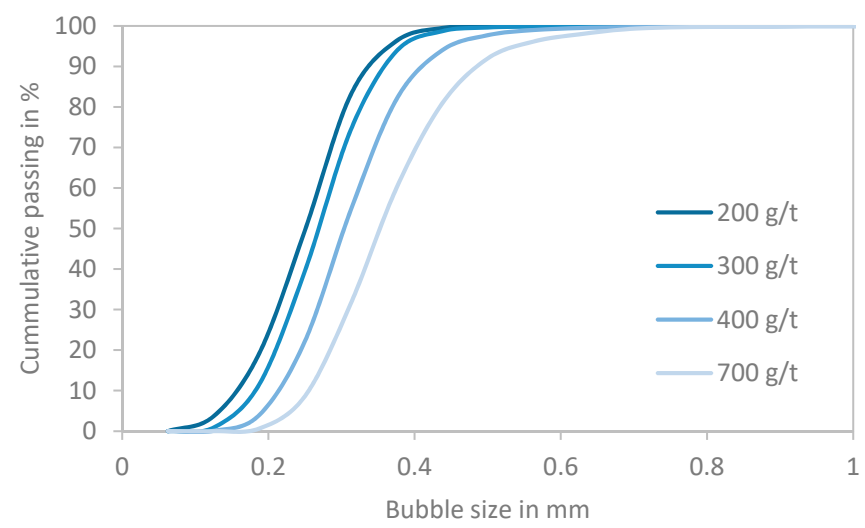

Figure 8. Bubble size distribution as a function of SHMP concentration.

\subsection{Effect of SHMP on the Sedimentation}

It is widely known that depressants mostly act as dispersants as well, which has a great capacity of dispersing fine particles; however, it also causes negative pulp effects in the downstream processes, such as in solid-liquid separation, i.e., thickening and filtration. As shown in Figure 9, the sedimentation ratio and settling speed decreases with an increase in the SHMP concentration. It was observed that the filtration of the tailings after flotation took longer with higher SHMP dosages. Hence, this effect needs to be considered in terms of flotation performance, downstream processes' cost and more importantly, the negative impact on the wastewater when using a high amount of SHMP.

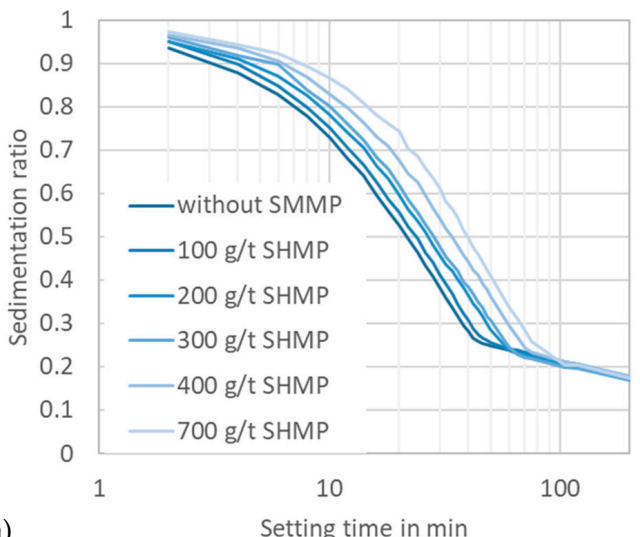

(a)

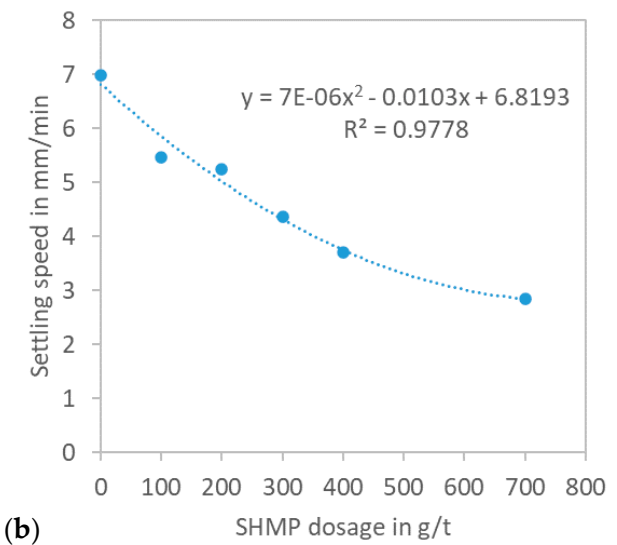

(b)

Figure 9. Effect of SHMP on the (a) sedimentation ratio and (b) settling speed after 2 min in bulk sedimentation.

The initial settling velocity is decreased by approximately a factor of two, comparing the pulp without SHMP and the pulp containing $700 \mathrm{~g} / \mathrm{t}$ of SHMP. By simple approximation using Stokes' settling velocity, relating the velocity to the particle (agglomerated) size squared, that would estimate the agglomerate size to be reduced by a factor of 0.7 due to the dispersing action of SHMP.

\subsection{Flotation Results}

\subsubsection{Water Pull vs. Mass Pull and Liquid Content}

As shown with the DFA investigations above, SHMP has influenced the froth properties quite significantly, i.e., froth height decreasing with an increase in the concentration of SHMP (Figure 5). Another way of looking at the change in the froth properties for a given system is plotting the mass recovery and water recovery from kinetic flotation tests. Figure 10 shows the influence of the SHMP concentration on these water and mass pulls in the batch flotation tests. 


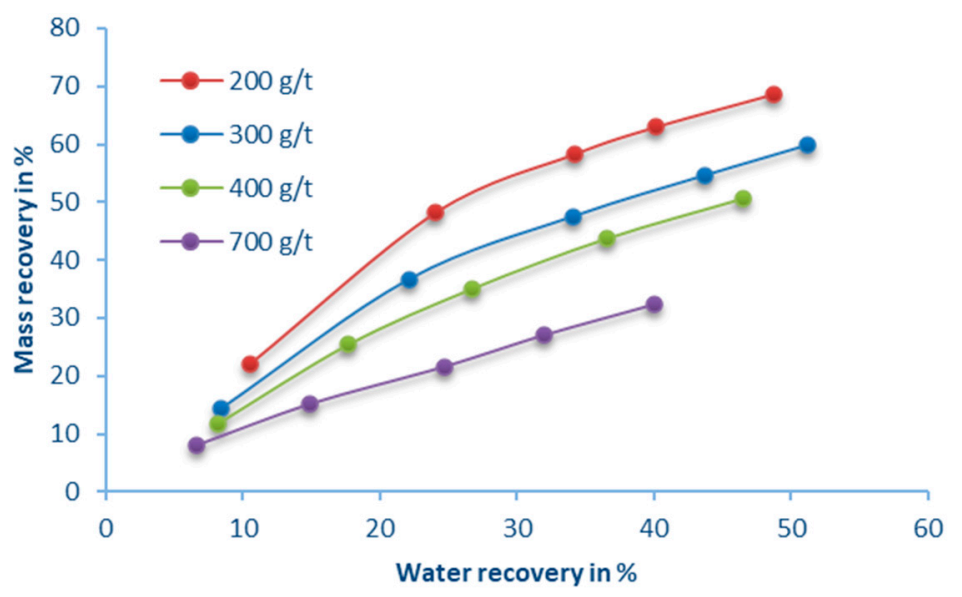

Figure 10. Mass pull vs. water pull.

The main finding of the above plot, however, is that the froth is getting wetter (higher water pull at the same mass pull) with an increasing SHMP concentration. Together with the finding that the bubble coalescence in the froth is much stronger as shown with DFA and that the overall particles are better dispersed, this can only mean that the lower mass recovered by the particles attached to the bubble surface (i.e., true flotation) and suspended in the lamella (i.e., entrained particles) are at the same water recovery, where water can only be recovered via the lamellae and must be governed by the lower fraction of true floating particles. Furthermore, Figure 10 shows the lower mass pull at the same water pull with increasing the SHMP concentration. SHMP is not sufficient to prevent the Resanol A100 collector interacting with mineral surfaces at a low concentration. This leads to an increase in both the recovery of valuable magnesite and the true flotation of calcium-carbonate gangue minerals (dolomite and calcite).

\subsubsection{Impact of SHMP on the Selectivity between Magnesite and Other Gangue Minerals}

In order to evaluate the separation efficiency of the valuable magnesite from the gangue minerals (dolomite, calcite, and quartz), the selectivity index (SI) was defined as a comprehensive evaluation criterion by considering the magnesite content in the feed and the concentrate, i.e., the magnesite and gangue recoveries. The SI is given in Equation (3) $[48,51]$.

$$
S I=\sqrt{\frac{R_{\mathrm{mag}} \times\left(100-R_{\mathrm{g}}\right)}{\left(100-R_{\mathrm{mag}}\right) \times R_{\mathrm{g}}}},
$$

where $R_{\mathrm{g}}$ is the recovery of the gangue mineral in the concentrate, i.e., dolomite, calcite and quartz, and $R_{\text {mag }}$ denotes the magnesite recovery.

Figure 11a indicates that SHMP not only depressed dolomite and calcite gangue minerals but also strongly influenced the magnesite recovery. The SHMP concentration shows a linear relationship with the magnesite recovery and mass pull. It demonstrates an effect on the quartz recovery as it ends up in the concentrate mainly by entrainment, and as shown before entrainment is effected by SHMP concentration via the dispersion as well as the froth structure. Figure $11 \mathrm{~b}$ also shows the selectivity index between magnesite and other gangue minerals. As shown in Figure 11, a low SHMP consumption (e.g., below $200 \mathrm{~g} / \mathrm{t}$ ) is not sufficient to prevent the collector absorption on the dolomite and calcite gangue minerals effectively, thus high recoveries of these minerals result in a low selectivity index. At a low SHMP dosage, the dolomite floated well but then the floating slowed. However, it has a strong effect on the magnesite recovery, as shown in Figure 11a, with a linear relationship between magnesite recovery and SHMP dosage. 


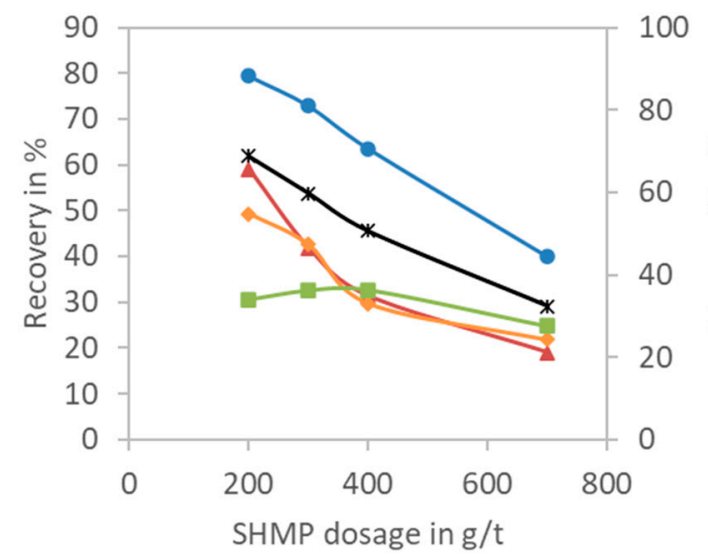

(a)

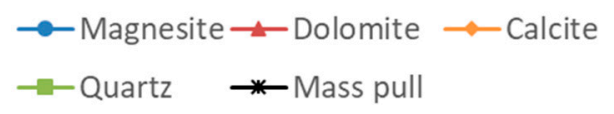

Figure 11. Effect of sodium hexametaphosphate consumption on the recovery (a) and (b) selectivity between magnesite and gangue minerals.

Figure 12 shows that SHMP has a beneficial impact on the magnesite and dolomite in terms of grade, i.e., the magnesite grade increased from $67 \%$ to $77 \%$ and reduced the dolomite content from $29 \%$ to $18 \%$ as the SHMP increased from $200 \mathrm{~g} / \mathrm{t}$ to $700 \mathrm{~g} / \mathrm{t}$. However, there is a trade-off between quality and recovery, when the SHMP increases, the magnesite and dolomite recoveries decrease massively from $80 \%$ to $40 \%$ and $59 \%$ to $20 \%$, respectively. Surprisingly, the $\mathrm{SiO}_{2}$ content in the concentrate increased with an increase in the SHMP concentration (Figure 12b). As a dispersant, a higher SHMP concentration results in better dispersing of the fine particles, making it easier for the fine quartz particles to end up in the froth phase via entrainment. Furthermore, as shown above, an increase in the SHMP concentration leads to a decrease in the settling velocity, thus a lower "drop-back" occurs within the froth zone. In addition, due to the complex interactions between ions and mineral surfaces, the new formation of, i.e., $\mathrm{CaCO}_{3}, \mathrm{MgCO}_{3}, \mathrm{Ca}_{2} \mathrm{SiO}_{4}$, or $\mathrm{Mg}_{2} \mathrm{SiO}_{4}$ on the quartz surface might change its hydrophobicity, thus the true flotation of the quartz gangue minerals.

It is often emphasized that flotation is a very complex process that is influenced by many factors. Hence, it is a challenge to seek the optimal conditions of individual parameters due to the interaction between different factors, for example, the reactions between the reagents and free ions within the bulk pulp. Hence, in this study we are focusing on the effect of the SHMP, and it is shown in Figure 11 that the SHMP dosage of about $300 \mathrm{~g} / \mathrm{t}$ to $400 \mathrm{~g} / \mathrm{t}$ gave the best performance. In consequence, this reagent regime is applied for the cleaner flotation study (see Section 3.6).

\subsubsection{Replacement of SHMP by a Novel Depressant}

The 1-hydroxyethylene-1,1-diphosphonic acid (HEDP) belongs to the etidronic acid type. It is a rather low toxic and environmentally benign organic phosphate compound, which is rather inexpensive and quite common. It is a reagent widely used in water treatment. Yang et al. [14] applied HEDP on the flotation of pure minerals, and it was shown to be a very promising depressant with a very selective depression in dolomite. X-ray photoelectron spectroscopy (XPS) and infrared spectrum (IR) analyses indicated that the HEDP that strongly adsorbed onto the dolomite in advance occupies a large number of calcium sites, whereas it had only slightly depressed magnesite. Also, the addition of HEDP prior to sodium oleate $(\mathrm{NaOl})$ had no significant impact on the adsorption of $\mathrm{NaOl}$ onto magnesite, while it prevented the adsorption of this collector onto the dolomite surface [14]. 
Figure $12 \mathrm{a}, \mathrm{b}$ indicate that using only $350 \mathrm{~g} / \mathrm{t}$ of HEDP can achieve a similar grade $(76.3 \%)$ as $700 \mathrm{~g} / \mathrm{t}$ of SHMP $(76.9 \%)$, while it has little effect on the magnesite recovery. The magnesite recovery is about $57 \%$ compared to $40 \%$ when using $700 \mathrm{~g} / \mathrm{t}$ of SHMP. Most importantly, the hydrophilic quartz mineral ending up in the concentrate is lower than in the case of using SHMP (Figure 12b). HEDP effectively depresses dolomite, resulting in a low dolomite grade of $18 \%$ as similar to the case of using $700 \mathrm{~g} / \mathrm{t}$ of SHMP (Figure 12c), and it shows very good selectivity between magnesite and dolomite (Figure 12d).
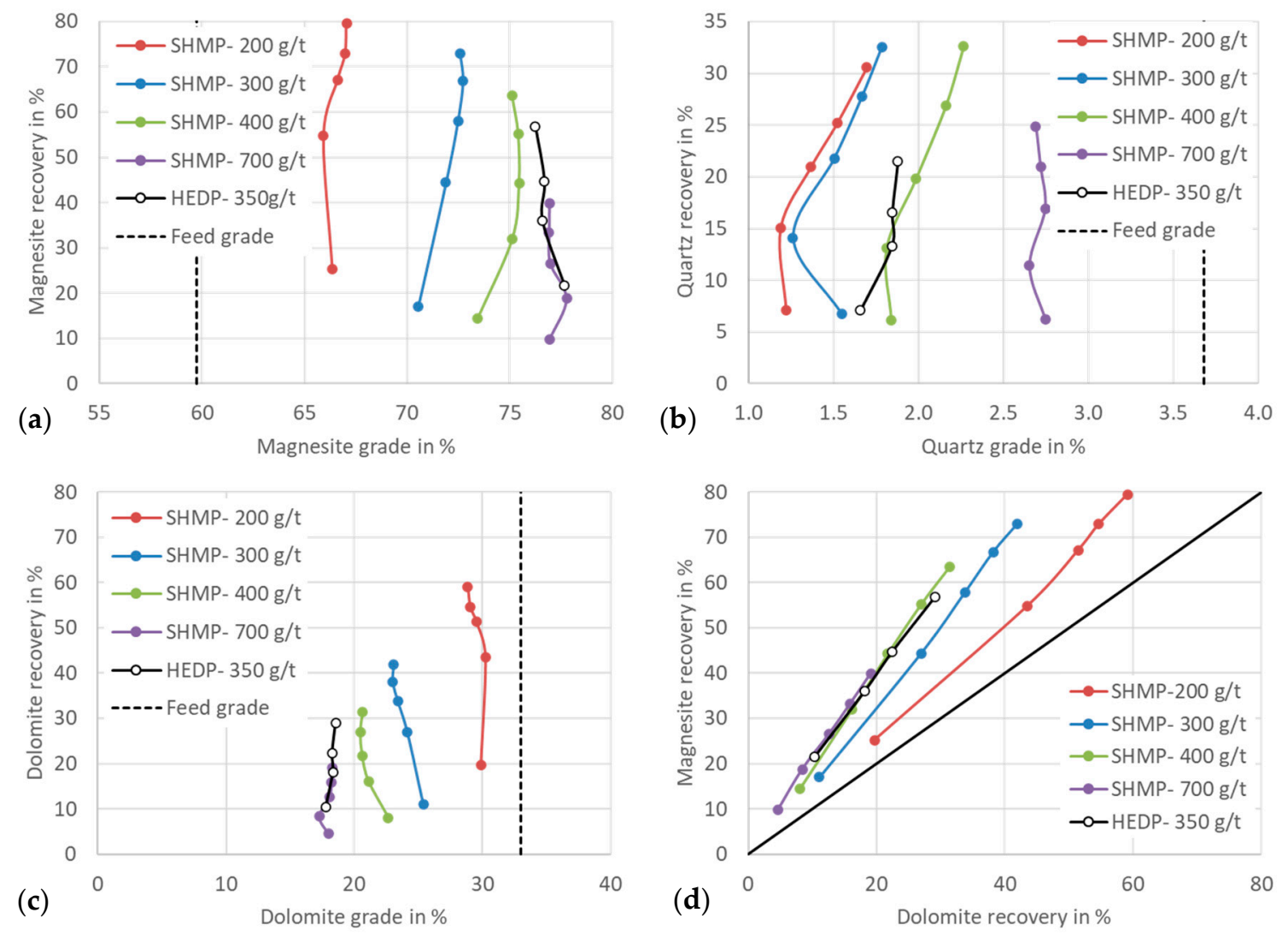

Figure 12. Effect of SHMP and HEDP as the depressants on the grade-recovery of (a) magnesite, (b) quartz, and (c) dolomite, and (d) selectivity curves (Fuerstenau upgrading curve) of magnesite against dolomite.

\subsubsection{Estimation of the Degree of Entrainment}

It is well documented that the entrainment is strongly dependent on the water pull, which is the carrying medium to transfer the entrained particles into the concentrate. For the fine particles, recovery by entrainment is showing a linear relationship with water recovery. Figure 10 shows both a water and mass pull rate increase with the decreasing in the SHMP concentration. The lower water pull results in reducing the degree of entrainment with an increase in the SHMP concentration. The entrainment factor $E F$ is defined as the ratio of the free gangue particles $R_{\mathrm{g}}$ to the water recovery $R_{\mathrm{W}}[52,53]$. The automated mineralogy data showed that quartz is mostly liberated (Figure 4 ). Hence, for the entrainment calculations all the quartz particles were taken into account. This is based on the assumption of solely reaching the concentrate by entrainment.

It is widely known that pulp density has a marked effect on the recovery by entrainment [54-57]. Figure 13 shows the solid content of the concentrates decreases with an increase in the flotation time and at higher SHMP concentrations, resulting in a lower pulp density, particularly for the low SHMP concentrations. Hence, EF decreases with the flotation time (Figure 14) due to the increasing settling velocity as a decrease in pulp density. Interestingly, for the first concentrate, the $E F$ is increasing with an increase in 
SHMP concentrations. As mentioned above, SHMP influences the state of dispersion at higher SHMP concentrations, thus the settling velocity is reduced and the fine quartz particles (smallest size, $d_{p}=6.2 \mu \mathrm{m}$ (Figure 1)) more quickly end up in the froth phase. In contrast, by the end of the flotation test (i.e., concentrates 4 and 5), different behavior can be seen, as a higher SHMP dosage results in decreasing the $E F$, which may be due to the water pull effect with a more stable froth at lower SHMP concentrations. As mentioned above, increasing the SHMP concentration results in a decrease in the dynamic stability factor and half-life time of the bubbles, thus reducing the entrained quartz particles into the concentrate.

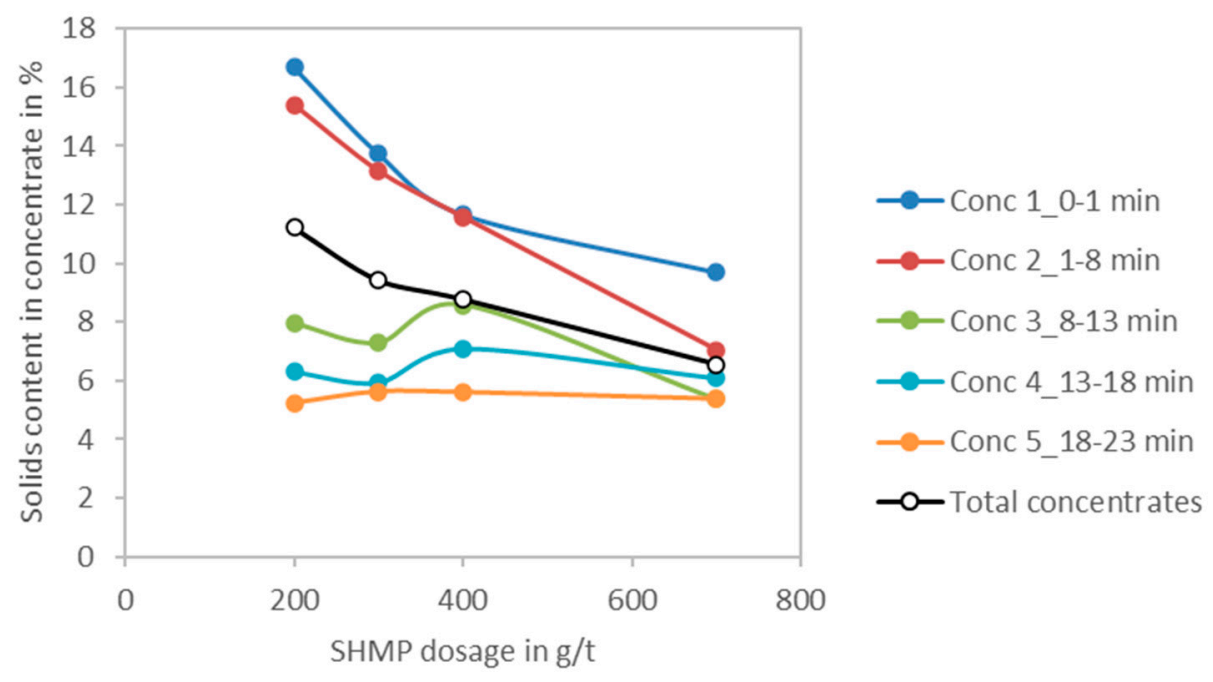

Figure 13. Solid content of concentrates as a function of SHMP concentration and flotation times.

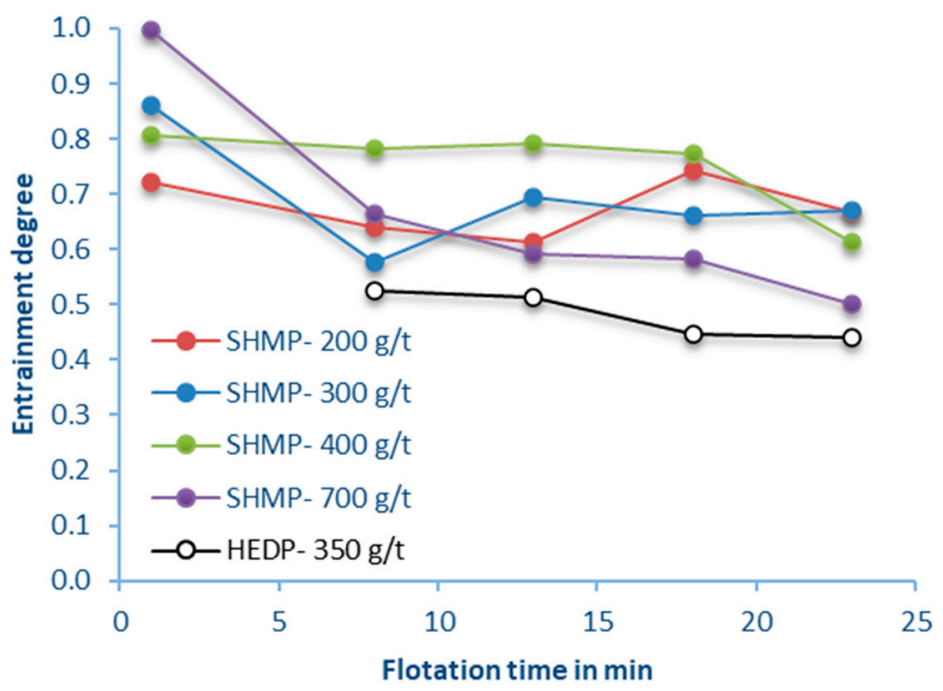

Figure 14. Entrainment factor for quartz minerals as a function of SHMP concentration and flotation times.

Interestingly, when using HEDP, the EF is lower compared to the SHMP for all the different concentrations. This is another advantage of applying HEDP as a novel depressant, selectively depressing dolomite while reducing the entrained quartz gangue mineral at the same time. 


\subsection{Cleaning Tests}

The $300 \mathrm{~g} / \mathrm{t}$ concentration of SHMP was considered, showing the best performance in terms of selectivity between valuable magnesite and other gangue minerals (dolomite, calcite and quartz) (Figure 11). Hence, for this concentration cleaner stages are investigated. With a rougher (two tests) followed by four cleaner steps, a feed ore containing about $59 \%$ magnesite, 33\% dolomite and $4 \%$ quartz was enriched to a concentrate assaying $77.5 \%$ magnesite at a recovery of $45.5 \%$ (Figure 15). The dolomite content in the concentrate was about $20 \%$, where $80 \%$ of the dolomite was removed and importantly $98 \%$ of the quartz was removed, only $0.3 \%$ of the quartz was in the final concentrate.

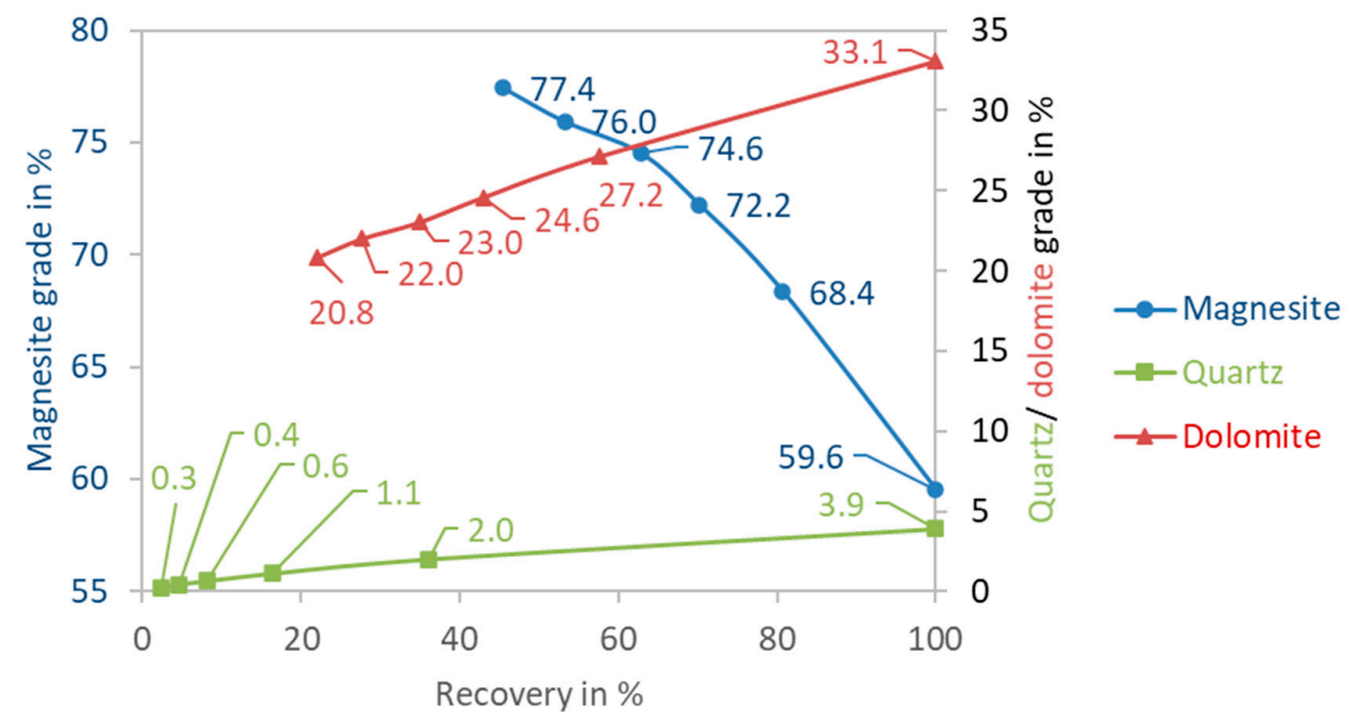

Figure 15. Upgrading the concentrate with cleaning stages.

As shown in Figure 15, more cleaner stages lead to an increase in the magnesite grade and a decrease in the unwanted gangue minerals (i.e., dolomite and quartz). In contrast, this leads to a decrease in the recovery as well. There is a trade-off between the number of cleaner stages to achieve balance in terms of magnesite grade and recovery. The results were performed with the open circuits; however, these trends would be useful to design the flowsheet in order to obtain the final concentrate, which meets the requirement for calcination and sintering in terms of technical and economic considerations.

\subsection{Interaction within the Bulk Pulp}

The solution thermodynamics of systems containing various suspended semi-soluble salt-type minerals and flotation reagents are rather complex. Magnesite, dolomite and calcite minerals are sparingly soluble and will release their lattice constituents into the solution, resulting in a high $\mathrm{Ca}^{2+} / \mathrm{Mg}^{2+}$ ion concentration within the bulk pulp. In addition to the dissolution of minerals and the adsorption of dissolved mineral and reagent species at the interface, the interactions between these species in the bulk can lead to complicated phenomena such as surface and bulk precipitation as well as the re-dissolution of adsorbed species [5].

As can be seen in Figure 16, the $\mathrm{Ca}^{2+} / \mathrm{Mg}^{2+}$ concentration in the conditioning stage (before reagents added) is higher than their concentration in tap water (i.e., $\mathrm{Ca}^{2+}$ ca. $22.5 \mathrm{mg} / \mathrm{L}$, $\mathrm{Mg}^{2+}$ ca. $3.7 \mathrm{mg} / \mathrm{L}$ ). It was also observed that the $\mathrm{pH}$ increases during conditioning, which demonstrated that fine minerals were diluted in the solutions. Figure 16 shows that the ions concentration at the end of flotation reduced significantly, even though the tap water was added to maintain the pulp level. All the used reagents (soda $\mathrm{Na}_{2} \mathrm{CO}_{3}$, sodium silicate $\mathrm{Na}_{2} \mathrm{SiO}_{3}$, sodium hexametaphosphate $\mathrm{Na}_{6}\left[\left(\mathrm{PO}_{3}\right)_{6}\right]$, and Resanol A100 collector) can interact with $\mathrm{Ca}^{2+} ; \mathrm{Mg}^{2+}$ ions, species $\mathrm{CO}_{3}{ }^{2-}$ or $\mathrm{SiO}_{3}{ }^{2-}$ to precipitate calcium/magnesium 
silicate, calcite $\mathrm{CaCO}_{3}$, etc., changing the mineral surfaces and consuming reagents, which is the reason for this significant decrease in the ion concentrations (Figure 16).

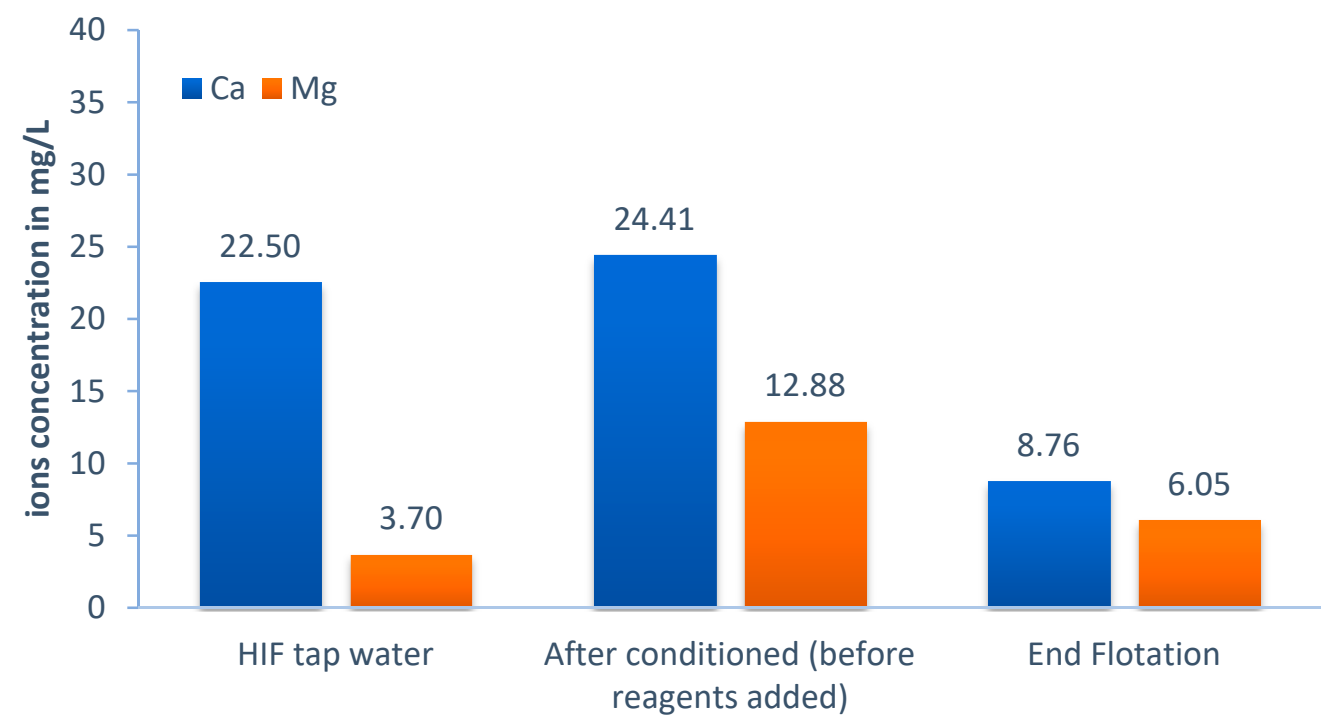

Figure 16. Variation in calcium and magnesium bivalents' concentrations during flotation.

\section{Conclusion and Recommendations}

For the first time a batch flotation study of slime magnesite tailings rich in dolomite is presented. Flotation separation faces many challenges due to ultrafine particles of semi-soluble salt-type minerals and the complex interactions between flotation reagents, dissolved ions, species, and mineral surfaces. The depressants, SHMP and HEDP were shown to be highly potent in magnesite dolomite-rich flotation, not only affecting the flotation performance by means of selectivity but also exposing a significant impact on the pulp and froth properties, and with that influencing downstream processes like dewatering. Through batch flotation testwork on the slime magnesite tailings, sedimentation tests and dynamic froth analysis, the following conclusions were reached:

- A suitable reagent regime has been found to reprocess the desliming fines, currently discarded to the tailing due to mainly a lack of flotation technologies (reagents and flotation cell for the ultrafine particles);

- With higher SHMP concentrations, the magnesite grade was improved while reducing the dolomite content. The reagents consumption is relatively high due to the high specific surface area of the fine particles and the high $\mathrm{Mg}^{2+}$ or $\mathrm{Ca}^{2+}$ ion concentration, which could interact with reagents;

- The open circuit with four cleaning stages obtained a concentrate assaying $77.5 \%$ magnesite at a recovery of $45.5 \%$ from slime tailings containing about $59 \%$ magnesite, $33 \%$ dolomite and $4 \%$ quartz. The dolomite content in concentrate is about $20 \%$, where $80 \%$ of the dolomite was removed and importantly $98 \%$ of the quartz was removed, only $0.3 \%$ of the quartz was in the final concentrate;

- As a dispersant, SHMP has a significant influence on the settling speed, thus negatively affecting the downstream processing and water treatment;

- The frothing ability and froth stability, by means of the dynamic stability factor and half-life time of bubbles, decrease when increasing the SHMP concentration, affecting the entrained hydrophilic quartz particles;

- As the SHMP concentration increases, the $\mathrm{SiO}_{2}$ content increases. The entrainment factor decreases with flotation time due to the significant change in froth properties and pulp density in the case of the batch lab-scale flotation of the rather high-grade ore; 
- There is a trade-off when changing the SHMP dosages and the number of cleaner stages to achieve balance in terms of magnesite grade and recovery. These trends would be useful to design the reagents regime and flowsheet in order to obtain the final concentrate, which meets the requirement for calcination and sintering in terms of technical and economic considerations;

- Applying HEDP as a common, and rather cheap reagent shows a promising result that might consider replacing SHMP in the flotation of magnesite rich in dolomite ores. Using only $350 \mathrm{~g} / \mathrm{t}$ of HEDP can achieve a similar grade (76.3\%) like $700 \mathrm{~g} / \mathrm{t}$ of SHMP $(76.9 \%)$, while it has little effect on the magnesite recovery. The magnesite recovery is about $57 \%$ compared to $40 \%$ when using $700 \mathrm{~g} / \mathrm{t}$ SHMP. Furthermore, the hydrophilic quartz minerals proportion ending up in the concentrate is lower for HEDP with only $1.9 \%$ quartz at the recovery of $21.5 \%$ as compared to the $2.7 \%$ of quartz at a recovery of $24.9 \%$ when using SHMP;

- With rather low flotation kinetics due to fine and ultrafine particles present, the flotation time was relatively long, at about $23 \mathrm{~min}$. The European FineFuture project (Horizon2020 funding from 2019-2022) is working on innovative technologies, including developing the new reagents, applying the advanced technologies to generate fine bubbles, and a high shear environment, which will improve and speed-up the flotation separation of fine particles. In this context, a pilot Maelgwyn pneumatic/reactorseparator Imhoflot ${ }^{\mathrm{TM}} \mathrm{G}$-cells with a throughput up to $5 \mathrm{~m}^{3} / \mathrm{h}$ has been constructed and the up-scaling testworks are ongoing and will be reported soon.

Author Contributions: Conceptualization, D.H.H. and M.R.; methodology, D.H.H.; D.E., R.M. and M.R.; software, D.H.H. and D.E.; validation, D.H.H., D.E. and R.M.; formal analysis, D.H.H. and D.E.; investigation, D.H.H.; resources, D.H.H. and D.E.; data curation, D.E. and D.H.H.; writingoriginal draft preparation, D.H.H.; writing-review and editing, D.H.H., M.R., D.E. and R.M.; visualization, D.H.H.; supervision, M.R. All authors have read and agreed to the published version of the manuscript.

Funding: This paper has received financial support from the European Union's Horizon 2020 research and innovation program under grant agreement no. 821265-FineFuture.

Acknowledgments: The authors would like to acknowledge Pilar Perez and Antonio Maldonado at Magnesitas Navarras, Spain for their discussions and providing the ore samples in this study. Further thanks to Arsenii Rybalchenko, Luciana Rodrigues de Faria and Juan Sebastian Barajas Narvaez for the sample preparation. Anja Oestreich for conducting the DFA measurements, Kai Bachman for conducting the MLA measurements, Markus Buchmann for his discussions, as well as Klaus Graebe for assisting the sedimentation tests. We would like to thank our colleagues at Maelgwyn Mineral Services for their support, special thanks to Rainer Imhof for his discussions. To our FineFuture partners and coordinators, many thanks for their discussion and support.

Conflicts of Interest: The authors declare no conflict of interest.

\section{References}

1. Wonyen, D.G.; Kromah, V.; Gibson, B.; Nah, S.; Chelgani, S.C. A Review of Flotation Separation of Mg Carbonates (Dolomite and Magnesite). Minerals 2018, 8, 354. [CrossRef]

2. Baudet, G.; Save, M. Phosphoric esters as carbonate collectors in the flotation of sedimentary phosphate ores. In Beneficiation of Phosphates: Advances in Research and Practice; Society for Mining, Metallurgy \& Exploration: Englewood, CO, USA, 1999; pp. 163-185.

3. Komar Kawatra, S.; Carlson, J.T. Beneficiation of Phosphate Ore; Society for Mining, Metallurgy \& Exploration: Englewood, CO, USA, 2014.

4. McClellan, G.H.; Van Kauwenbergh, S.J. Mineralogical and chemical variation of francolites with geological time. J. Geol. Soc. 1991, 148, 809-812. [CrossRef]

5. Somasundaran, P.; Wang, D. Chapter 4 Mineral-flotation reagent equilibria. In Developments in Mineral Processing; Dianzuo, W., Ed.; Elsevier: Amsterdam, The Netherlands, 2006; Volume 17, pp. 73-141.

6. Fuerstenau, D.W.; Deason, D.M. Effect of surface transformation processes on the surface chemistry and flotation behavior of dolomite and apatite. In Proceedings of the XVII International Mineral Processing Congress, Dresden, Germany, September 1991; pp. 71-91. 
7. Kou, J.; Tao, D.; Xu, G. Fatty acid collectors for phosphate flotation and their adsorption behavior using QCM-D. Int. J. Miner. Process. 2010, 95, 1-9. [CrossRef]

8. Karlkvist, T. Selectivity in Calcium Mineral Flotation-An Analysis of Novel and Existing Approaches. Ph.D. Thesis, Lulea University of Technology, Lulea, Sweden, 2017.

9. Sis, H.; Chander, S. Reagents used in the flotation of phosphate ores: A critical review. Miner. Eng. 2003, 16, 577-585. [CrossRef]

10. Smolko-Schvarzmayr, N.; Klingberg, A.; Henriksson, E.; Nordberg, H. Use of branched alcohols and alkoxylates thereof as secondary collectors. U.S. Patent 2017/0252753 A1, 7 September 2017.

11. Miller, J.D.; Wang, X.; Li, M. Bench scale flotation of sedimentary phosphate rock with hydroxamic acid collectors. In Engineering Foundation Conference, Beneficiation of Phosphates III: Fundamentals and Technology; Zhang, P., El-Shall, H., Somasundaran, P., Stana, R., Eds.; Society for Mining, Metallurgy \& Exploration: Englewood, CO, USA, 2002; pp. 93-101.

12. Miller, J.D.; Wang, X.; Li, M. Selective Flotation of Phosphate Minerals with Hydroxamate Collectors. U.S. Patent 6341697B1, 29 January 2002.

13. Karlkvist, T.; Patra, A.; Rao, K.H.; Bordes, R.; Holmberg, K. Flotation selectivity of novel alkyl dicarboxylate reagents for apatite-calcite separation. J. Colloid Interface Sci. 2015, 445, 40-47. [CrossRef] [PubMed]

14. Yang, B.; Wang, D.; Cao, S.; Yin, W.; Xue, J.; Zhu, Z.; Fu, Y.; Yao, J. Selective adsorption of a high-performance depressant onto dolomite causing effective flotation separation of magnesite from dolomite. J. Colloid Interface Sci. 2020, 578, 290-303. [CrossRef] [PubMed]

15. Luo, N.; Wei, D.; Shen, Y.; Han, C.; Zhang, C. Elimination of the Adverse Effect of Calcium Ion on the Flotation Separation of Magnesite from Dolomite. Minerals 2017, 7, 150. [CrossRef]

16. Matis, K.A.; Balabanidis, T.H.N.; Gallios, G.P. Processing of magnesium carbonate fines by dissolved-air flotation. Colloids Surf. 1988, 29, 191-203. [CrossRef]

17. Matis, K.A.; Gallios, G.P. Anionic flotation of magnesium carbonates by modifiers. Int. J. Miner. Process 1989, 25, 261-274. [CrossRef]

18. Yao, J.; Sun, H.; Han, F.; Yin, W.; Hong, J.; Wang, Y.; Won, C.; Du, L. Enhancing selectivity of modifier on magnesite and dolomite surfaces by $\mathrm{pH}$ control. Powder Technol. 2020, 362, 698-706. [CrossRef]

19. Gallios, G.P.; Matis, K.A. Floatability of Magnesium Carbonates by Sodium Oleate in the Presence of Modifiers. Sep. Sci. Technol. 1989, 24, 129-143. [CrossRef]

20. Fuerstenau, M.C.; Han, K.N. Principles of Mineral Processing; Society for Mining, Metallurgy \& Exploration: Englewood, CO, USA, 2003.

21. Ozkan, S.G. Beneficiation of magnesite slimes with ultrasonic treatment. Miner. Eng. 2002, 15, 99-101. [CrossRef]

22. Luo, X.; Wang, Y.; Wen, S.; Ma, M.; Sun, C.; Yin, W.; Ma, Y. Effect of carbonate minerals on quartz flotation behavior under conditions of reverse anionic flotation of iron ores. Int. J. Miner. Process. 2016, 152, 1-6. [CrossRef]

23. Li, D.; Yin, W.-z.; Xue, J.-W.; Yao, J.; Fu, Y.-f.; Liu, Q. Solution chemistry of carbonate minerals and its effects on the flotation of hematite with sodium oleate. Int. J. Miner. Metall. Mater. 2017, 24, 736-744. [CrossRef]

24. Yao, J.; Yin, W.; Gong, E. Depressing effect of fine hydrophilic particles on magnesite reverse flotation. Int. J. Miner. Process. 2016, 149, 84-93. [CrossRef]

25. Yin, W.; Sun, H.; Hong, J.; Cao, S.; Yang, B.; Won, C.; Song, M. Effect of Ca selective chelator BAPTA as depressant on flotation separation of magnesite from dolomite. Miner. Eng. 2019, 144, 106050. [CrossRef]

26. Rebolledo, E.; Laskowski, J.S.; Gutierrez, L.; Castro, S. Use of dispersants in flotation of molybdenite in seawater. Miner. Eng. 2017, 100, 71-74. [CrossRef]

27. Ramirez, A.; Rojas, A.; Gutierrez, L.; Laskowski, J.S. Sodium hexametaphosphate and sodium silicate as dispersants to reduce the negative effect of kaolinite on the flotation of chalcopyrite in seawater. Miner. Eng. 2018, 125, 10-14. [CrossRef]

28. Li, W.; Li, Y. Improved understanding of chalcopyrite flotation in seawater using sodium hexametaphosphate. Miner. Eng. 2019, 134, 269-274. [CrossRef]

29. Li, W.; Li, Y.; Xiao, Q.; Wei, Z.; Song, S. The Influencing Mechanisms of Sodium Hexametaphosphate on Chalcopyrite Flotation in the Presence of $\mathrm{MgCl}_{2}$ and $\mathrm{CaCl}_{2}$. Minerals 2018, 8, 150. [CrossRef]

30. Kupka, N.; Rudolph, M. Role of sodium carbonate in scheelite flotation-A multi-faceted reagent. Miner. Eng. 2018, 129, 120-128. [CrossRef]

31. Hasson, D.; Shemer, H.; Sher, A. State of the Art of Friendly "Green" Scale Control Inhibitors: A Review Article. Ind. Eng. Chem. Res. 2011, 50, 7601-7607. [CrossRef]

32. Huang, Z.; Wang, J.; Sun, W.; Hu, Y.; Cao, J.; Gao, Z. Selective flotation of chalcopyrite from pyrite using diphosphonic acid as collector. Miner. Eng. 2019, 140, 105890. [CrossRef]

33. Wang, J.; Zhou, Z.; Gao, Y.; Sun, W.; Hu, Y.; Gao, Z.J.M. Reverse flotation separation of fluorite from calcite: A novel reagent scheme. Minerals 2018, 8, 313. [CrossRef]

34. Schubert, H. On the optimization of hydrodynamics in fine particle flotation. Miner. Eng. 2008, 21, 930-936. [CrossRef]

35. Hoang, D.H.; Heitkam, S.; Kupka, N.; Hassanzadeh, A.; Peuker, U.A.; Rudolph, M. Froth properties and entrainment in lab-scale flotation: A case of carbonaceous sedimentary phosphate ore. Chem. Eng. Res. Des. 2019, 142, 100-110. [CrossRef]

36. Farrokhpay, S. The significance of froth stability in mineral flotation-A review. Adv. Colloid Interface Sci. 2011, 166, 1-7. [CrossRef]

37. Schwarz, S. The Relationship Between Froth Recovery and Froth Structure; University of South Australia: Adelaide, Australia, 2004. 
38. Pugh, R.J. Foaming, foam films, antifoaming and defoaming. Adv. Colloid Interface Sci. 1996, 64, 67-142. [CrossRef]

39. Bikerman, J.J. Foams; Springer: New York, NY, USA, 1973.

40. Mackay, I.; Mendez, E.; Molina, I.; Videla, A.R.; Cilliers, J.J.; Brito-Parada, P.R. Dynamic froth stability of copper flotation tailings. Miner. Eng. 2018, 124, 103-107. [CrossRef]

41. McFadzean, B.; Achaye, I.; Chidzanira, T.; Harris, M. The effect of particle size on froth stabilities of different ores. In Proceedings of the XXVIII International Mineral Processing Congress Proceedings, Quebec City, QC, Canada, 1-15 September 2016.

42. McFadzean, B.; Marozva, T.; Wiese, J. Flotation frother mixtures: Decoupling the sub-processes of froth stability, froth recovery and entrainment. Miner. Eng. 2016, 85, 72-79. [CrossRef]

43. Heinig, T.; Bachmann, K.; Tolosana-Delgado, R.; Van Den Boogaart, G.; Gutzmer, J. Monitoring gravitational and particle shape settling effects on MLA sampling preparation. In Proceedings of the IAMG, Freiberg, Germany, 5-13 September 2015; pp. 200-206.

44. Fandrich, R.; Gu, Y.; Burrows, D.; Moeller, K. Modern SEM-based mineral liberation analysis. Int. J. Miner. Process. 2007, 84, 310-320. [CrossRef]

45. Hoang, D.H.; Kupka, N.; Peuker, U.A.; Rudolph, M. Flotation study of fine grained carbonaceous sedimentary apatite oreChallenges in process mineralogy and impact of hydrodynamics. Miner. Eng. 2018, 121, 196-204. [CrossRef]

46. Leißner, T.; Hoang, D.H.; Rudolph, M.; Heinig, T.; Bachmann, K.; Gutzmer, J.; Schubert, H.; Peuker, U.A. A mineral liberation study of grain boundary fracture based on measurements of the surface exposure after milling. Int. J. Miner. Process. 2016, 156, 3-13. [CrossRef]

47. Doebelin, N.; Kleeberg, R. Profex: A graphical user interface for the Rietveld refinement program BGMN. J. Appl. Crystallogr. 2015, 48, 1573-1580. [CrossRef] [PubMed]

48. Hoang, D.H.; Hassanzadeh, A.; Peuker, U.A.; Rudolph, M. Impact of flotation hydrodynamics on the optimization of fine-grained carbonaceous sedimentary apatite ore beneficiation. Powder Technol. 2019, 345, 223-233. [CrossRef]

49. Boos, J.; Drenckhan, W.; Stubenrauch, C. Protocol for Studying Aqueous Foams Stabilized by Surfactant Mixtures. J. Surfactants Deterg. 2013, 16, 1-12. [CrossRef]

50. Wang, Y.; Neethling, S.J. The relationship between the surface and internal structure of dry foam. Colloids Surf. A Physicochem. Eng. Asp. 2009, 339, 73-81. [CrossRef]

51. Gaudin, A.M. Principles of Mineral Dressing; McGraw-Hill: New York, NY, USA, 1939.

52. Johnson, N.W. The Flotation Behaviour of Some Chalcopyrite Ores; University of Queensland Press: St. Lucia, QLD, Australia, 1972.

53. Yianatos, J.; Contreras, F. Particle entrainment model for industrial flotation cells. Powder Technol. 2010, 197, 260-267. [CrossRef]

54. Wang, L.; Peng, Y.; Runge, K. Entrainment in froth flotation: The degree of entrainment and its contributing factors. Powder Technol. 2016, 288, 202-211. [CrossRef]

55. Zheng, X.; Johnson, N.W.; Franzidis, J.P. Modelling of entrainment in industrial flotation cells: Water recovery and degree of entrainment. Miner. Eng. 2006, 19, 1191-1203. [CrossRef]

56. Yianatos, J.; Contreras, F.; Díaz, F.; Villanueva, A. Direct measurement of entrainment in large flotation cells. Powder Technol. 2009, 189, 42-47. [CrossRef]

57. Johnson, N. A review of the entrainment mechanism and its modelling in industrial flotation processes. In Proceedings of the Centenary of Flotation Symposium, Brisbane, Australia, 6-9 June 2005. 